\title{
ENTREPRENEURSHIP OF WOMEN AND MEN IN POLAND - JOB CHANGES OR BECOMING A FIRM OWNER
}

Katarzyna Białek*

\begin{abstract}
Background. Previous studies have established a negative relationship between becoming a firm owner and gender. A question may arise if there are any differences between those who change their job to wage employment and people who set up a company.
\end{abstract}

Research aims. This study examines the differences and similarities between women and men who switched to entrepreneurship and those who changed their job to labour employment.

Methodology. Data from the Social Diagnosis 2015 - Objective and Subjective Quality of Life in Poland Survey are used to examine the relationship. The study uses a classification tree to examine the differences. The factors examined are as follows: education level, age, region, size of the city, social variables, and psychological characteristics.

Key findings. We find that marital status and social capital are important for women who switched into entrepreneurship, while length of unemployment and experience in working abroad are significant for male entrepreneurs.

Keywords: gender, entrepreneurship, entrepreneur, self-employed.

\section{INTRODUCTION}

Women entrepreneurs constitute a minority of entrepreneurs in all countries. Previous studies have shown a negative relationship between gender and the probability of becoming a firm owner (van der Zwan et al., 2012). A question may arise if there are any differences between women and men who change their job to wage employment and those

\footnotetext{
" University of Warsaw. E-mail: kabialek@gmail.com
} 
who set up a company. Most of the research suggests that women and men entrepreneurs may have different socio-demographic characteristics like education, experience, social capital, or psychological characteristics from labour workers (Cowling \& Taylor, 2001; Blanchflower, 1998; Minniti \& Naudé, 2010; Liberda, Pęczkowski, 2011).

This work presents an empirical comparison between people who have just changed their job and those who establish business in Poland. The purpose of this article is to verify the hypothesis that switching to wage employment is affected by different factors than switching to entrepreneurship. Additionally, we verify if those factors are different for men and women. This article is divided into four parts. The subsequent sections discuss shortly the existing literature and the method used in the study. The next section presents the results of empirical analysis. The last section presents the conclusions.

\section{BACKGROUND}

This study contributes to the empirical literature on entrepreneurship, particularly to the perceiving of opportunities and occupational choice research. According to Kirzner (1999) individuals become entrepreneurs when they are able to notice and use the opportunities that are available to everybody. Opportunities can be perceived variously by different individuals, what can explain why only chosen people decide to use the opportunity and set up a firm. On the other hand the occupational choice theory suggests that people choose between different options taking into account future potential wage or profit - becoming an entrepreneur is one of those options. In the heterogeneity version of this theory individuals are equipped in some level of entrepreneurial capabilities, that are known to them and decide to start a business based on this knowledge and potential profits (Fon \& Lowrey, 2008). The question may arise if there are differences in characteristics between those who choose wage labour and decide to set up a firm. In other words, are there any characteristics that foster recognising and using opportunities.

Several studies have considered the ability of women and men to perceive and foster opportunities. Men constitute the majority of firm owners - only one-third of firm owners worldwide are women. Firms run by men are larger and have higher profits, while female firms often 
stay micro-enterprises (Minniti, 2010). Empirical studies have provided some evidence on the differences between women's and men's motivation to become a firm owner. The majority of them claim that women are motivated by family and lifestyle reasons, while for men more important are financial factors (Dawson et al., 2014; Kepler, Shane, 2007). Justo and DeTienne (2008) point out that married women have a higher probability to become entrepreneurs than non-married women. Generally, marital status seems to influence women's engagement in entrepreneurship (Edwards \& Field-Hendrey, 2002; van der Zwan et al., 2012).

The human capital theory highlights the importance of education and experience that can increase the ability of spotting opportunities. Lazear (2004; Oberschachtsiek, 2012) argues that people who become entrepreneurs have a more general strategy of investing in human capital than those who become employees. They have a large number of skills and a lot of different experience - they can be referred to as a jack-of-all-trade. Some of researchers (Minniti \& Naudé, 2010; Cowling \& Taylor, 2001) highlight the differences in human capital endowments between self-employed and labour workers in the context of gender. Others (Shim \& Eastlick, 1998) argue that the level of education for firm owners is quite high in comparison to other occupations, but there are no differences in education between women and men.

The third set of explanations for women's and men's decision of setting up a firm focuses on social capital endowments. Social capital might be a source of information for both people who set up a firm and those who change their job. Social capital is connected with the ability to perceive opportunities and increases trust. From the perspective of perceiving opportunities it is also important to take into account the quality of network including frequency and configuration of ties (Adler \& Kwon, 2002; Davidsson \& Honig, 2003).

Several studies focus on entrepreneurship in the context of unemployment. Evans and Leighton (1989) and Carrasco (1999) point out that people who experience repeated or long periods of unemployment move to self-employment with higher probability.

Entrepreneurship activities are embedded in a regional context. According to Stuetzer et al. (2014) regional economic background, knowledge creation, and entrepreneurship culture influence indirectly the perception of opportunities. Wach (2008) underlines the role of regional business environment in the stimulation of small firms and notices that the differences in entrepreneurship exist between regions. 
The empirical evidence for the impact of the size of the city on women's and men's entrepreneurship is mixed. On the one hand, Garcia (2012) shows that the number of new businesses is positively correlated with the size of the city. On the other hand, Gardawski (2013) in case of Poland argues that the size of city does not have a direct impact on entrepreneurship.

All in all, we can say that the decision about starting a business and moving to wage employment is influenced by various factors. Some of them seem to affect the decision of changing a job in the same way for women and men. Other factors have a different impact on male and female entrepreneurship.

\section{METHOD}

\section{Study design}

The focus of this analysis is to identify if there are any differences in characteristics of people who voluntary decide to change their job and those who decide to start their own firm.

Two hypotheses are verified:

H1: Switching to wage employment is affected by different factors than switching to entrepreneurship.

H2: Factors that affect a change of employment are different for men and women.

We test the hypotheses using the classification tree. This way of data analysis allows splitting a sample into similar groups. It is commonly used in many different fields including finance, sociology, biology, and medicine. The CHAID method of tree growing, that is used in this case, looks for variables that give the best classification into groups (Kass, 1980; Ritschard, 2010). The effectiveness of the classification is measured with a comparison between the number of cases that are classified by the algorithm based on characteristics to one of the group and real respondents' choices.

\section{Data}

The data for individuals from the Social Diagnosis 2015 Objective and Subjective Quality of Life in Poland is used in this study. The survey 
is conducted every other year by the Social Monitoring Council and it is a representative sample of the population of Poland. The database was selected to conduct this analysis as it contains not only economic and non-economic variables, but also the reasons for changing a job which is important for this study.

Table 1. The structure of the research sample

\begin{tabular}{|l|c|c|}
\hline \multicolumn{1}{|c|}{ Change in employment } & Number of responses & Percentage (\%) \\
\hline Voluntary to wage employment & 764 & 70 \\
\hline Setting up a firm & 335 & 30 \\
\hline Total & 1099 & 100 \\
\hline
\end{tabular}

Source: own development based on Social Diagnosis 2015 - Objective and Subjective Quality of Life in Poland Survey, Database of individuals, Poland, Social Monitoring Council, Warsaw.

In the survey, the respondents were asked about changing their job during the last 2 years and the reasons for this change. There are 1,892 respondents who are older than 18 years and had changed their job, for most of them the decision about their job change was made because of external factors. Better work/pay was a reason for job transition of 764 respondents. For the purpose of this study only data for those, who had declared that the change of the occupation was a result of their own decision, were taken into account. In case of this study the term entrepreneurs is used for respondents who declared that they had set up a firm (both self-employed and employers). The structure of the research sample is presented in Table 1.

Women constitute $41 \%$ of those who voluntary changed their job. In the survey there are no direct questions about the reasons for setting up a business and therefore all data for respondents who declared that they set up a company are used in the analysis. Men constitute the majority of new firm owners (65\%).

\section{Variables}

The list of variables that are selected for the analysis is shown in Table 2 and Table 3. As already mentioned the dependent variable - change of employment - consists of two categories (voluntary change to wage employment and setting up a firm) and it is a nominal variable. 
First group of independent variables constitutes demographic variables that are self-explanatory like age, marital status, and gender. We use a standard variable defining a person's relationship status - marital status with five levels: married, divorced, widow/ widower, single, and real separation (Table 2).

Table 2. List of independent variables used in classification tree part 1

\begin{tabular}{|c|c|c|}
\hline $\begin{array}{l}\text { Variable } \\
\text { group }\end{array}$ & Variable & $\begin{array}{l}\text { Variable } \\
\text { type }\end{array}$ \\
\hline \multirow[t]{3}{*}{ Demographics } & Gender & Nominal \\
\hline & Age in 2015 & Scale \\
\hline & Marital status & Nominal \\
\hline \multirow[t]{5}{*}{ Education } & Education level & Nominal \\
\hline & Number of years of education & Scale \\
\hline & Field of education & Nominal \\
\hline & $\begin{array}{l}\text { Knowledge of languages: English, German, French, Russian, } \\
\text { Spanish, Other }\end{array}$ & Nominal \\
\hline & Have you improved your skills during the last 2 years? & Nominal \\
\hline \multirow{3}{*}{$\begin{array}{l}\text { Living abroad } \\
\text { experience }\end{array}$} & $\begin{array}{l}\text { How long in total during the last } 2 \text { years have you studied } \\
\text { abroad (months)? }\end{array}$ & Scale \\
\hline & $\begin{array}{l}\text { How many times have you gone abroad in order to learn/work } \\
\text { during the last } 2 \text { years? }\end{array}$ & Scale \\
\hline & $\begin{array}{l}\text { How long in total during the last } 2 \text { years have you worked } \\
\text { abroad (months)? }\end{array}$ & Scale \\
\hline \multirow[t]{10}{*}{$\begin{array}{l}\text { Psychological } \\
\text { characteristics }\end{array}$} & In difficult situations I motivate myself and start actions & Nominal \\
\hline & $\begin{array}{l}\text { In difficult situations I console myself with the thought that it } \\
\text { could be worse/others have it worse }\end{array}$ & Nominal \\
\hline & $\begin{array}{l}\text { In difficult situations I do distracting things that make me } \\
\text { feel better }\end{array}$ & Nominal \\
\hline & In difficult situations I request a hint and help from other people & Nominal \\
\hline & In difficult situations I pray to God & Nominal \\
\hline & In difficult situations I give up and do not know what to do & Nominal \\
\hline & In difficult situations I drink alcohol & Nominal \\
\hline & In difficult situation I take sedatives & Nominal \\
\hline & What is more important in life? & Nominal \\
\hline & How do you evaluate your whole life? & Nominal \\
\hline \multirow[t]{2}{*}{ Region } & Province & Nominal \\
\hline & Size class of the town & Nominal \\
\hline
\end{tabular}

Source: own development based on Social Diagnosis 2015 - Objective and Subjective Quality of Life in Poland Survey, Database of individuals, Poland, Social Monitoring Council, Warsaw. 
The second group of independent variables is education. As it is outlined above, previous research does not agree on what influence this variable has on entrepreneurship (Davidsson \& Honig, 2003; Lazear, 2004, 2005). The education group includes standard variables like respondents' level of education, length of education, and the field of education, that may affect an employment status of a respondent as some of the education directions are more likely to be performed as self-employed (Davidsson \& Honig, 2003). Additionally, two non-standard variables are used. The first of those variables is knowledge of foreign languages, which may broaden the respondents' employment options. Another variable that is used in the analysis describes respondents' willingness to improve skills in the past.

Lazear (2004) argues that entrepreneurs are characterised by skills from different fields, not necessary by having a formal education. In our opinion, one of those skills can be experience gained during living abroad. Therefore, the other group of variables used in the analysis includes information about the experience of respondents living abroad. This group consists of a question about learning and working abroad. All of those variables are scale variables. The next group of variables describes if a person experienced unemployment periods in the past. This type of experience increases the probability of becoming a firm owner (Evans \& Leighton, 1989; Carrasco, 1999). Two variables are included in the analysis: information about unemployment in the past - length of unemployment in months and number of periods of unemployment during the last 2 years (see Table 3). Another group of independent variables used in the equation are variables that describe the respondents' social capital. This group is based on several categorical variables including engagement in local communities and trust (Welter, 2012; Welter \& Smallbone, 2006). As Bentolila at al. (2010) show, social relations are helpful in finding a job and shorten periods of unemployment. From the perspective of the entrepreneurship theory strong and weak ties may help a person to discover the opportunity and to developthe firm (Devece et. al., 2011; Santarelli \& Tran, 2013). There are also a few scale variables describing the number of friends and the frequency of contacts with members of a social network (Davidsson, Honig \& 2003; Ma et al., 2011). 
Table 3. List of independent variables used in classification tree part 2

\begin{tabular}{|c|c|c|}
\hline $\begin{array}{l}\text { Variable } \\
\text { group }\end{array}$ & Variable & $\begin{array}{l}\text { Variable } \\
\text { type }\end{array}$ \\
\hline \multirow[t]{10}{*}{ Social capital } & How many people you consider your friends? & Scale \\
\hline & $\begin{array}{l}\text { How many family members / friends / acquaintances do you } \\
\text { contact for social and personal purposes regularly (at least } \\
\text { several times a year)? }\end{array}$ & Scale \\
\hline & Do you have significantly older or younger acquaintances? & Nominal \\
\hline & Do you have acquaintances with a different political view? & Nominal \\
\hline & Do you have poorer or wealthier acquaintances? & Nominal \\
\hline & $\begin{array}{l}\text { Do you have acquaintances that prefer a different type of } \\
\text { music, literature, entertainment compared to yourself? }\end{array}$ & Nominal \\
\hline & $\begin{array}{l}\text { Do you have acquaintances with a different food taste com- } \\
\text { pared to yourself? }\end{array}$ & Nominal \\
\hline & In general do you think that you can trust most people? & Nominal \\
\hline & $\begin{array}{l}\text { In the last } 2 \text { years have you engaged in activities for the } \\
\text { local community? }\end{array}$ & Nominal \\
\hline & Did you vote in the last local elections in $2014 ?$ & Nominal \\
\hline \multirow[t]{2}{*}{ Unemployment } & How many times have you been unemployed? & Scale \\
\hline & $\begin{array}{l}\text { How long have you been unemployed in total during the } \\
\text { last } 2 \text { years? }\end{array}$ & Scale \\
\hline \multirow[t]{4}{*}{ View } & $\begin{array}{l}\text { In your opinion were the reforms after } 1989 \text { in Poland } \\
\text { successful? }\end{array}$ & Nominal \\
\hline & How often do you take part in religious services & Scale \\
\hline & $\begin{array}{l}\text { Which sentence about democracy do you find the most } \\
\text { relevant for you? }\end{array}$ & Nominal \\
\hline & Which political party is the most relevant for you? & Nominal \\
\hline
\end{tabular}

Source: own development based on Social Diagnosis 2015 - Objective and Subjective Quality of Life in Poland Survey, Database of individuals, Poland, Social Monitoring Council, Warsaw.

The next two groups include variables describing views and psychological characteristics of the respondents. Some of the research indicates that entrepreneurs have a strong opinion about the world (Low \& MacMillan, 1988). Therefore, in the first group political opinions and participation in religious services are considered. The group of psychological characteristics covers the respondents' reaction in difficult situations, things that are important in life and the respondents' evaluation of their lives (Łaguna, 2010). Finally, variables describing institutions and business environment are 
added to the analysis. Those variables are size class of the town and province (Bergmann \& Sternberg, 2006; Stuetzer et al., 2014). The size of the city appears as a binary variable in 5 categories: city up to 20 thousand inhabitants, between 20 and 100 thousand inhabitants, 100 and 500 thousand inhabitants and more than 500 thousand inhabitants, and rural areas.

\section{RESULTS}

In this part we present the results of an empirical analysis. The classification tree is quite complex, so simplified diagrams are used to present the main results. A detailed classification tree can be found in Appendix section.

The classification tree summary is presented in Table 4 . The tree classifies about $79 \%$ of respondents in a proper way: $88 \%$ of those who changed their job voluntarily and $60 \%$ of respondents who started a company. Gender is a forced variable, nonetheless it appears to be significant $\left(\mathrm{X}^{2}=3.94, \mathrm{p}<0.05\right)$.

Table 4. Classification tree statistics summary

\begin{tabular}{|l|c|c|c|}
\hline \multirow{2}{*}{ Observed } & \multicolumn{3}{|c|}{ Predicted } \\
\cline { 2 - 4 } & $\begin{array}{c}\text { Voluntary } \\
\text { to wage employment }\end{array}$ & $\begin{array}{c}\text { Setting up } \\
\text { a firm }\end{array}$ & $\begin{array}{c}\text { Percent Correct } \\
(\%)\end{array}$ \\
\hline Voluntary to wage employment & 671 & 93 & 88 \\
\hline Setting up a firm & 134 & 201 & 60 \\
\hline Overall Percentage (\%) & 73 & 27 & 79 \\
\hline Growing method & & & CHAID \\
\hline Risk estimated & & & 0.21 \\
\hline Std. Error & & & 0.01 \\
\hline
\end{tabular}

Source: own development based on Social Diagnosis 2015 - Objective and Subjective Quality of Life in Poland Survey, Database of individuals, Poland, Social Monitoring Council, Warsaw.

In the case of females (Figure 1) it appears that the variable, which significantly differentiates between respondents who voluntarily changed their job and new firm owners is marital status. Women, who are single or in separation, changed their job to wage employment and rather did not decide to start up a company. Also to this group belong other female respondents who: 
a) meet with no more than 5 acquaintances and live in central Poland;

b) meet with no more than 5 acquaintances, live in the east or west of Poland and have equal or less than 13 years of schooling;

c) meet with more than 5 acquaintances, believe that meaning of life is more important and take part in religious services not more than twice a month.

Women, who decided to set up a business, are characterised with the following combinations of profiles:

a) they are married now or were married in the past, meet with no more than 5 acquaintances, live in the east or west of Poland and have more than 13 years of schooling;

b) they are married now or were married in the past, meet with more than 5 acquaintances and declared that pleasure is more important than meaning in life more important in life;

c) they are married now or were married in the past, meet with more than 5 acquaintances, meaning in life is more important than pleasure for them and they take part in religious services more than twice a month.

The branch for men, which is presented on Figure 2, is more complex than the branch for women. The first variable that differentiates between the respondents who voluntarily changed their job and those who set up a firm is the length of unemployment during the last two years. The group of respondents who have been unemployed is dominated by those who voluntarily changed their job for better work/pay. Those respondents, who voluntarily changed their work, constitute also a majority in the following combination of profiles:

a) have not been unemployed and have spent equal or less than 18 months working abroad;

b) have not been unemployed, have spent more than 18 months working abroad, have been engaged in activities for the local community and know German;

c) have not been unemployed, have spent more than 18 months working abroad, have not been engaged in activities for the local community, live in a town of less than 200 thousand inhabitants, declare that they have active knowledge of English, and evaluate their whole life negatively;

d) have not been unemployed, have spent more than 18 months working abroad, have not engaged in activities for the local 
community, live in a town of less than 200 thousand inhabitants, evaluate their whole life positively, did not vote in the local elections in 2014, or voted and agree that the reforms after 1989 were successful;

e) have not been unemployed, have spent more than 18 months working abroad, have not been engaged in activities for the local community, live in a city with more than 500 thousand inhabitants, are single or married and have a differentiated social network by age, and live in southern and western Poland.

Men who set up a company have not been unemployed during last two years and have worked abroad for at least 18 months during the last two years. Additionally, those respondents can be characterised by the following variables:

a) they have been engaged in activities for the local community and do not know German;

b) they have not engaged in activities for the local community and live in a city between 200-500 thousand inhabitants;

c) they did have not been engaged in activities for the local community and live in a town of up to 200 thousand inhabitants, declare that they have active knowledge of English and evaluate their life positively, they voted in the last local elections, but they evaluate reforms after 1989 negatively;

d) they have not been engaged in activities for the local community and live in a city of over 500 thousand inhabitants or in a rural area, are married and have a homogenous social network or have a differentiated social network and live in northern, central, and eastern Poland.

The analysis provides evidence that switching to wage employment is affected by different factors than switching to entrepreneurship. Additionally, those factors seem to be different for women and men. These estimation results support the set hypothesis, however further research, especially with different analysis techniques, is required to examine the relationship. 


\section{VOLUNTARY CHANCE}

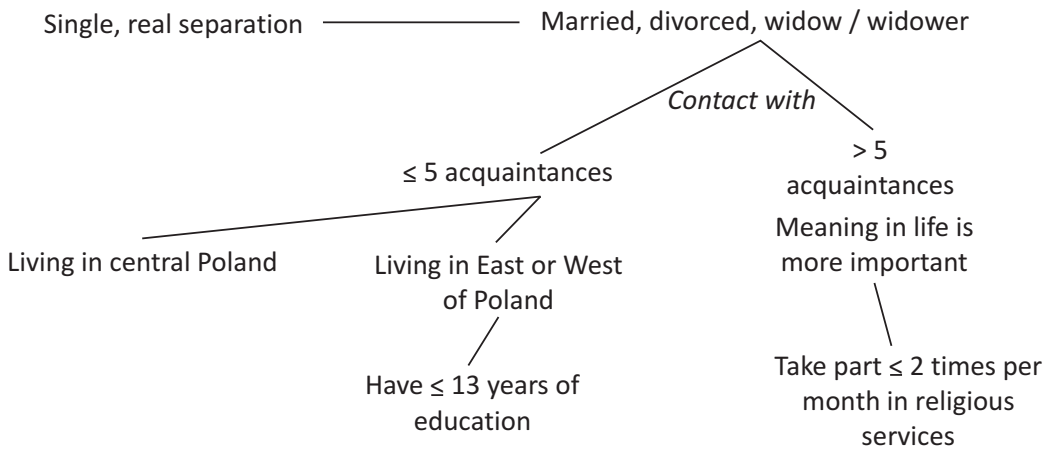

SET UP A FIRM

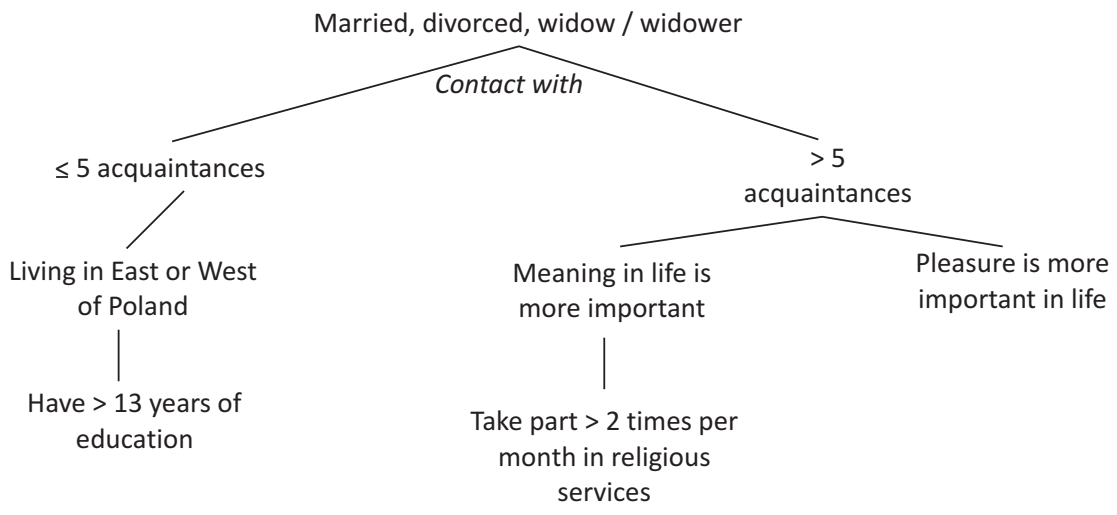

Figure 1. Summary of the branch for females

Source: own development based on Social Diagnosis 2015 - Objective and Subjective Quality of Life in Poland Survey, Database of individuals, Poland, Social Monitoring Council, Warsaw. 


\section{VOLUNTARY CHANCE}

Has been unemployed in the last 2 years Has not been unemployed in the last 2 years
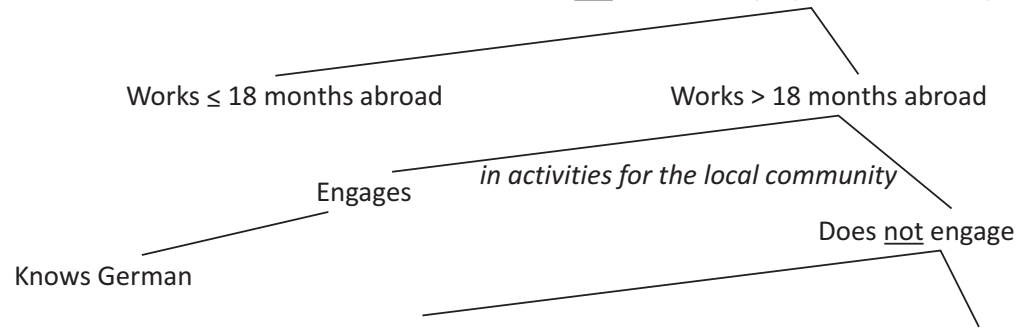

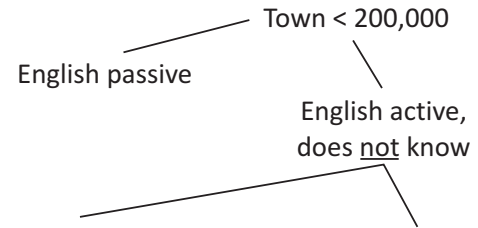

Rates life negatively/neutral

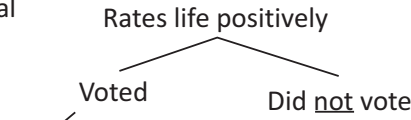

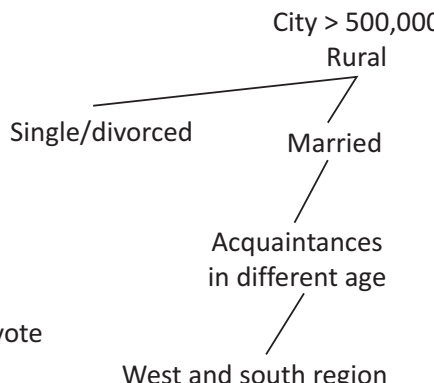

Reforms in Poland have been successful

SET UP A FIRM

Has not been unemployed in the last 2 years

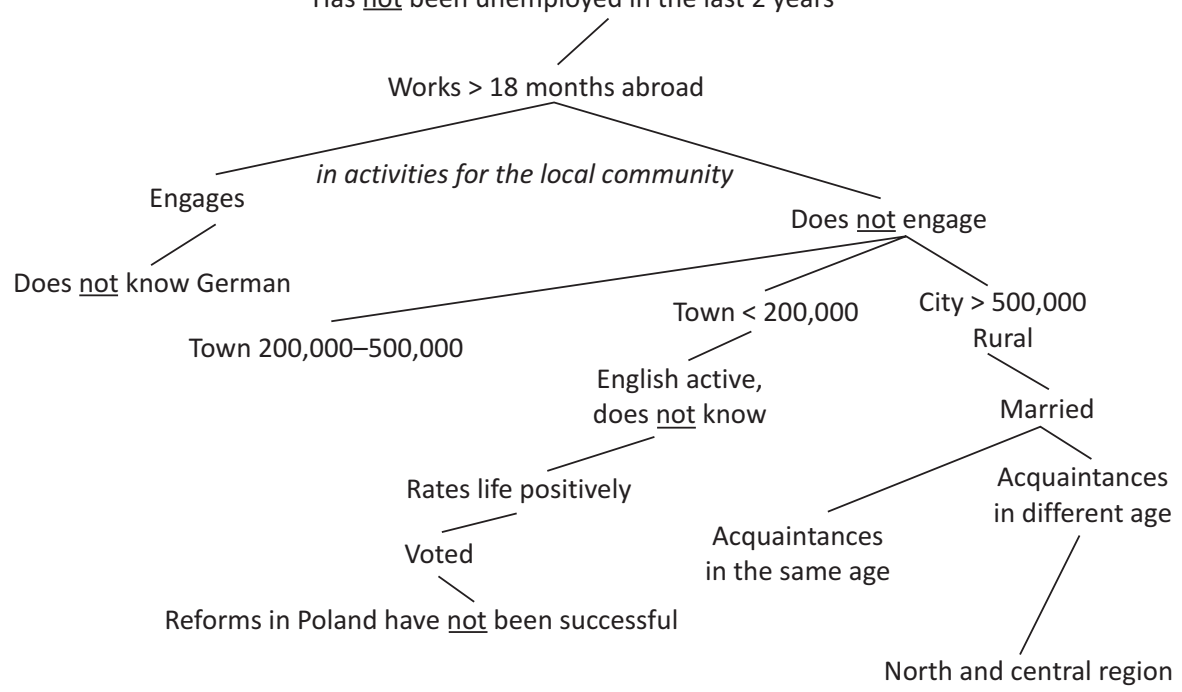

Figure 2. Summary of the branch for males

Source: own development based on Social Diagnosis 2015 - Objective and Subjective Quality of Life in Poland Survey, Database of individuals, Poland, Social Monitoring Council, Warsaw. 


\section{DISCUSSION \& CONCLUSIONS}

In this article we make an attempt to study the differences between females and males who switched into entrepreneurship and those who chose labour work in Poland. To bring the paper to a close we summarise the main points below.

First of all, gender is a significant variable that differentiates those who change their job and those who set up a company.

Secondly, marital status and the number of acquaintances with whom the respondents meet during the year were important for separating women into two research groups. This variable was not important for men.

Lastly, in case of men, not having periods of unemployment and having experience in working abroad characterises mainly those who had switched to entrepreneurship.

This study has also several limitations. First and foremost, the database used for the analysis does not contain information about the number of years of experience and income before changing the job. Additionally, data about changing the job concerns the last 2 years, but evidence about setting up a firm is connected only with the previous year. Furthermore, the method used in the study does not provide information about causality - it only classifies the respondents to similar groups. Some of the variables that are treated as independent variables may be in fact a consequence of the respondents' activity. 


\section{REFERENCES}

Adler, P.S., \& Kwon, S.W. (2002). Social Capital: Prospects for a New Concept. The Academy of Management Review, 27(1), 17-40.

Bergmann, H. \& Sternberg, R. (2006). The Changing Face of Entrepreneurship in Germany. Small Business Economics, 28(2-3), 205-221.

Bentolila, S., Michelacci, C. \& Suarez, J. (2010). Social Contacts and Occupational Choice. Economica, London School of Economics and Political Science, 77(305), 20-45.

Blanchflower, D.G. \& Oswald, A.J. (1998). What Makes an Entrepreneur? Journal of Labor Economics, 16(1), 26-60.

Carrasco, R. (1999). Transition to and from Self-employment in Spain: An Empirical Analysis. Oxford Bulletin of Economics and Statistics, 61(3), 315-341.

Cowling, M. \& Taylor, M. (2001). Entrepreneurial women and men: Two different species? Small Business Economics, 16(3), 167-176.

Davidsson, P. \& Honig, B. (2003). The role of social and human capital among nascent entrepreneurs. Journal of Business Venturing, 18(3), 301-331.

Dawson, Ch., Henley, A. \& Letreille, P.L. (2014). Individual Motives for Choosing Self-employment in the UK: Does Region Matter? Regional Studies, 48(5), 804-822.

Devece, C.A., Palacios-Marques, D. \& Fernandez, R. (2011). Entrepreneurship Research in Service Industries: a Literature Classification and Trend Analysis. International Entrepreneurship and Management Journal, 7(4), 479-493.

Evans, D.S. \& Leighton, L.S. (1989). Some empirical aspects of entrepreneurship. The American Economic Review, 79(3), 519-535.

Edwards, L. \& Field-Hendrey, E. (2002). Home-based work and women's labor force decisions. Journal of Labor Economics, 20(1), 170-200.

Fon, V. \& Lowrey, Y. (2008). Entrepreneurial Activities: A Microeconomic Analysis. SSRN, No. 1158147, 1-24.

Garcia, A.B. (2012). Analyzing the determinants of entrepreneurship in European cities. Small Business Economics, 42(1), 77-98.

Gardawski, J. (2013). Rzemieślnicy i biznesmeni właściciele małych i średnich przedsiębiorstw prywatnych. Warsaw: Wydawnictwo Naukowe Scholar.

Jaworek, M. \& Zachorowska-Mazurkiewicz, A. (2015). Gender as a category of analysis in the social sciences. In: E. Okoń-Horodyńska \& A. Zachorowska-Mazurkiewicz (eds.), Statistical Profiles of Women's and Men's Status in the Economy Science and Society. Cracow: Jagiellonian University Press. 
Justo, R. \& DeTienne, D.R. (2008). Gender, Family Situation and the Exit Event: Reassessing the Opportunity-Cost of Business Ownership. Madrid IE Business School Working Paper, WP08-26.

Kass, G.V. (1980). An Exploratory Technique for Investigating Large Quantities of Categorical Data. Applied Statistics, 29(2), 119-127.

Kepler, E. \& Shane, S. (2007). Are Male and Female Entrepreneurs Really that Different? Small Business Research Summary, 309, 1-59.

Kirzner, I. (1999). Creativity and/or Alertness: A Reconsideration of Schumpeterian Entrepreneur. Review of Austrian Economics, 11(1), 5-17.

Lazear, E.P. (2004). Balanced Skills and Entrepreneurship. The American Economic Review, 94(2), 208-211.

Lazear, E.P. (2005). Entrepreneurship. Journal of Labor Economics, 23(4), 649-680.

Liberda, B.Z. \& Pęczkowski, M. (2011). Does a change of occupation lead to higher earnings? Statistics in Transition - new series, 12(1), 193-206.

Low, M.B. \& MacMillan, I.C. (1988). Entrepreneurship: Past research and future challenges. Journal of Management, 14(2), 139-161.

Łaguna, M. (2010). Przekonania na własny temat $i$ aktywność celowa. Badania nad przedsiębiorczościa, t. 12. Gdańsk: Gdańskie Wydawnictwo Psychologiczne.

Ma, R., Huang, Y.C. \& Shenkar, O. (2011). Social Networks and Opportunity Recognition: A Cultural Comparison between Taiwan and United States. Strategic Management Journal, 32(11), 1183-1205.

Minniti, M. (2010). Female entrepreneurship and economic activity. European Journal of Development Research, 22(3), 294-312.

Minniti, M. \& Naudé, W. (2010). What Do We Know about the Patterns and Determinants of Female Entrepreneurship across Countries? European Journal of Development Research, 22(3), 277-293.

Oberschachtsiek, D. (2012). The experience of the founder and self-employment duration: a comparative advantage approach. Small Business Economics, 39(1), 1-17.

Ritschard, G. (2010). CHAID and Earlier Supervised Tree Methods. Research Papers by the Institute of Economics and Econometrics, Geneva School of Economics and Management, University of Geneva, 2010.02, 1-28.

Rollnik-Sadowska, E. (2010). Przedsiębiorczość kobiet w Polsce. Warsaw: Difin.

Santarelli, E. \& Tran, H.T. (2013). The Interplay of Human and Social Capital in Shaping Entrepreneurial Performance: The Case of Vietnam. Small Business Economics, 40(2), 435-458.

Shim, S. \& Eastlick, M.A. (1998). Characteristics of Hispanic Female Business Owners: An Exploratory Study. Journal of Small Business Management, 36(3), 18-34. 
Social Monitoring Council (2015). Social Diagnosis, Questionnaires. [Online] Retrieved from: http://www.diagnoza.com (access: 25.04.2016).

Stuetzer, M., Obschonka, M., Brixy, U., Sternberg, R. \& Cartner, U. (2014). Regional characteristics, opportunity perception and entrepreneurial activities. Small Business Economics, 42(2), 221-244.

Tyrowicz, J. (2011). What Distinguishes Entrepreneurs? Evidence on the Motives for Self-employment. Economics Letters, 12(3), 226-229.

Wach, K. (2008). Impact of the regional business environment on the development of small and medium-sized enterprises in Southern Poland. MPRA Paper, 31488 ,

Welter, F. (2012). All you need is trust? A critical review of the trust and entrepreneurship literature. International Small Business Journal, 30(3), 193-212.

Welter, F. \& Smallbone, D. (2006). Exploring the Role of Trust in Entrepreneurial Activity. Entrepreneurship Theory and Practice, 30(4), 465-475.

Zwan, P.Z. van der, Verheul, I. \& Thurik, R.A. (2012). The entrepreneurial ladder, gender, and regional development. Small Business Economics, 39(3), 627-643. 


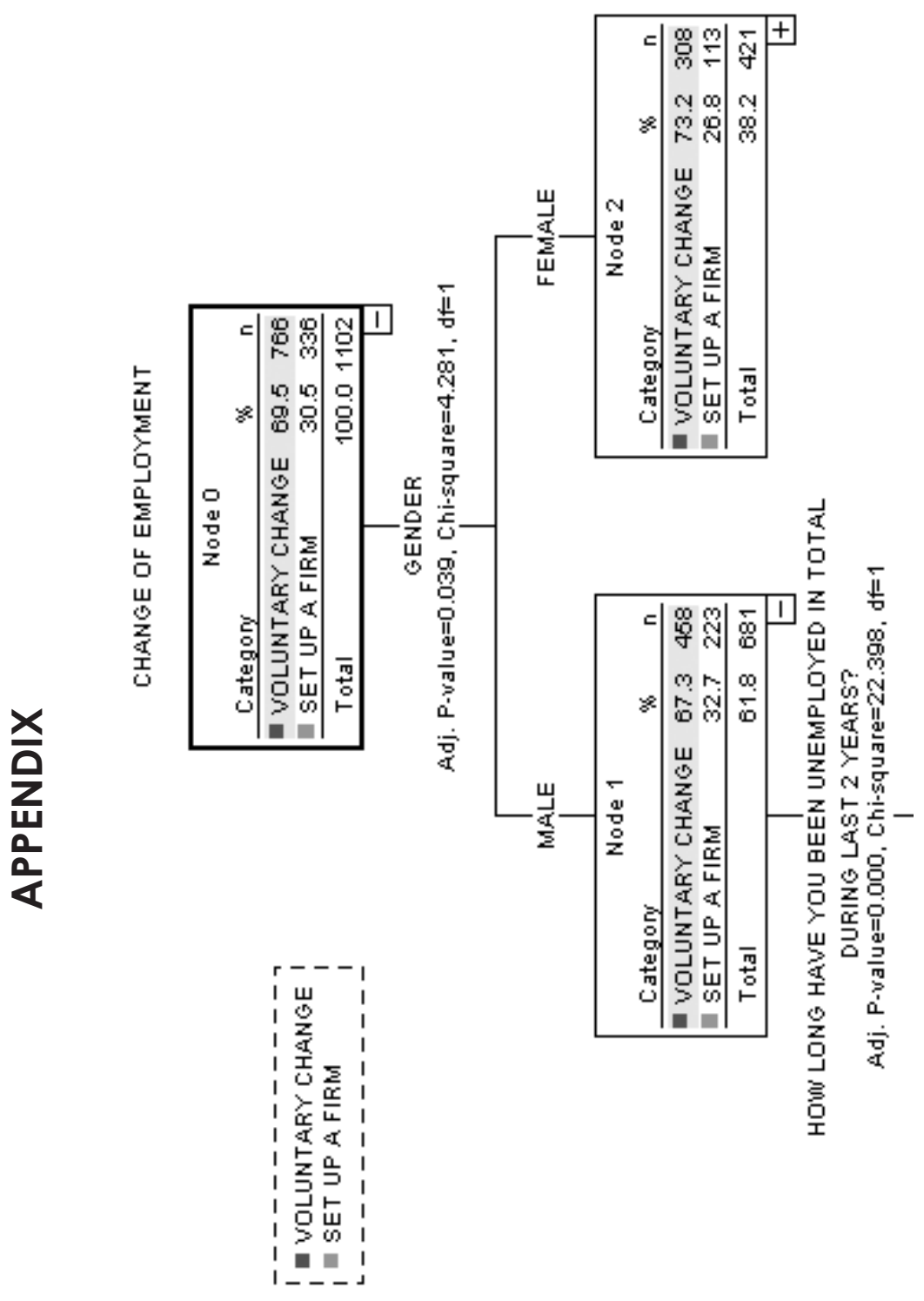




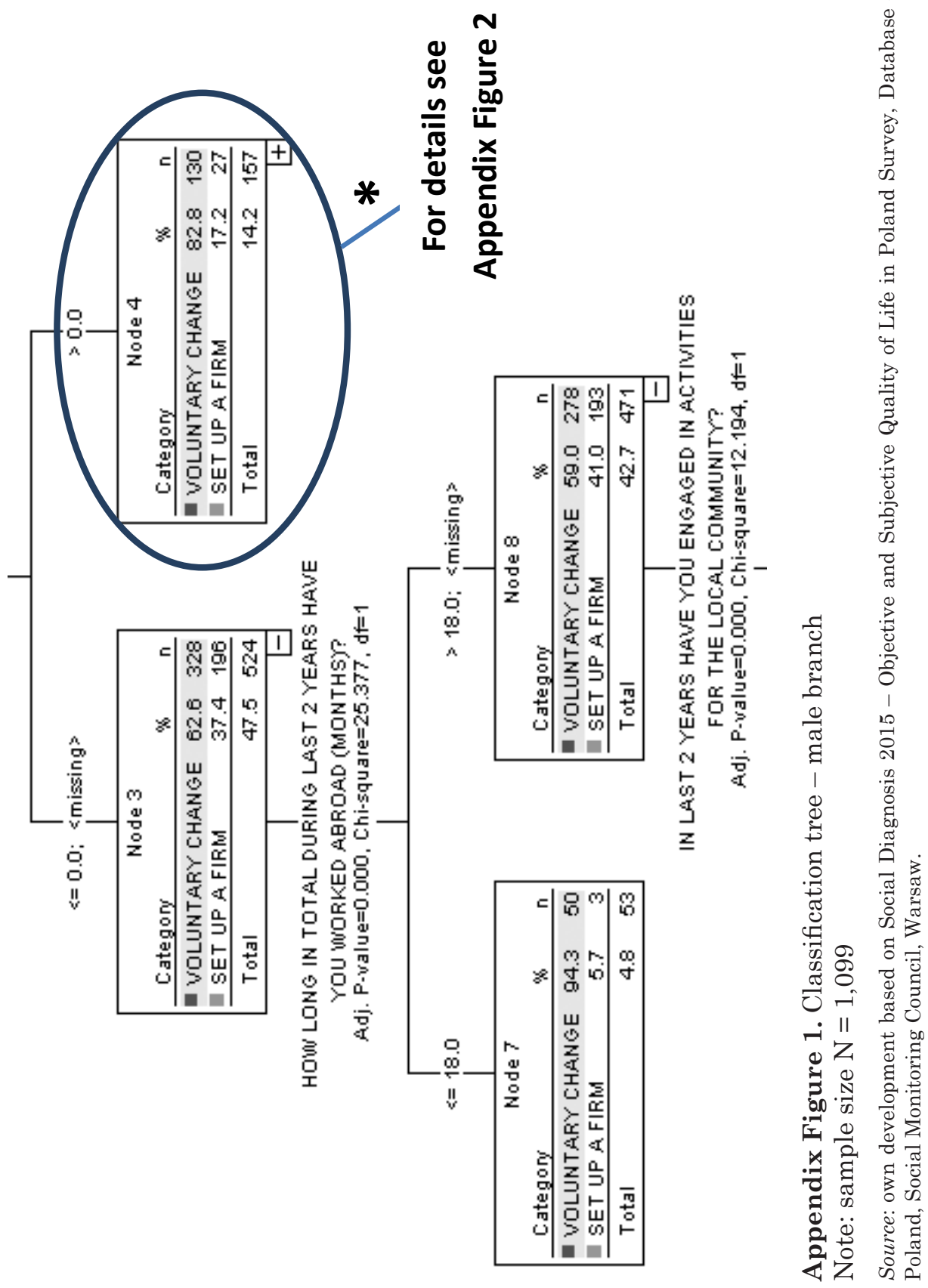



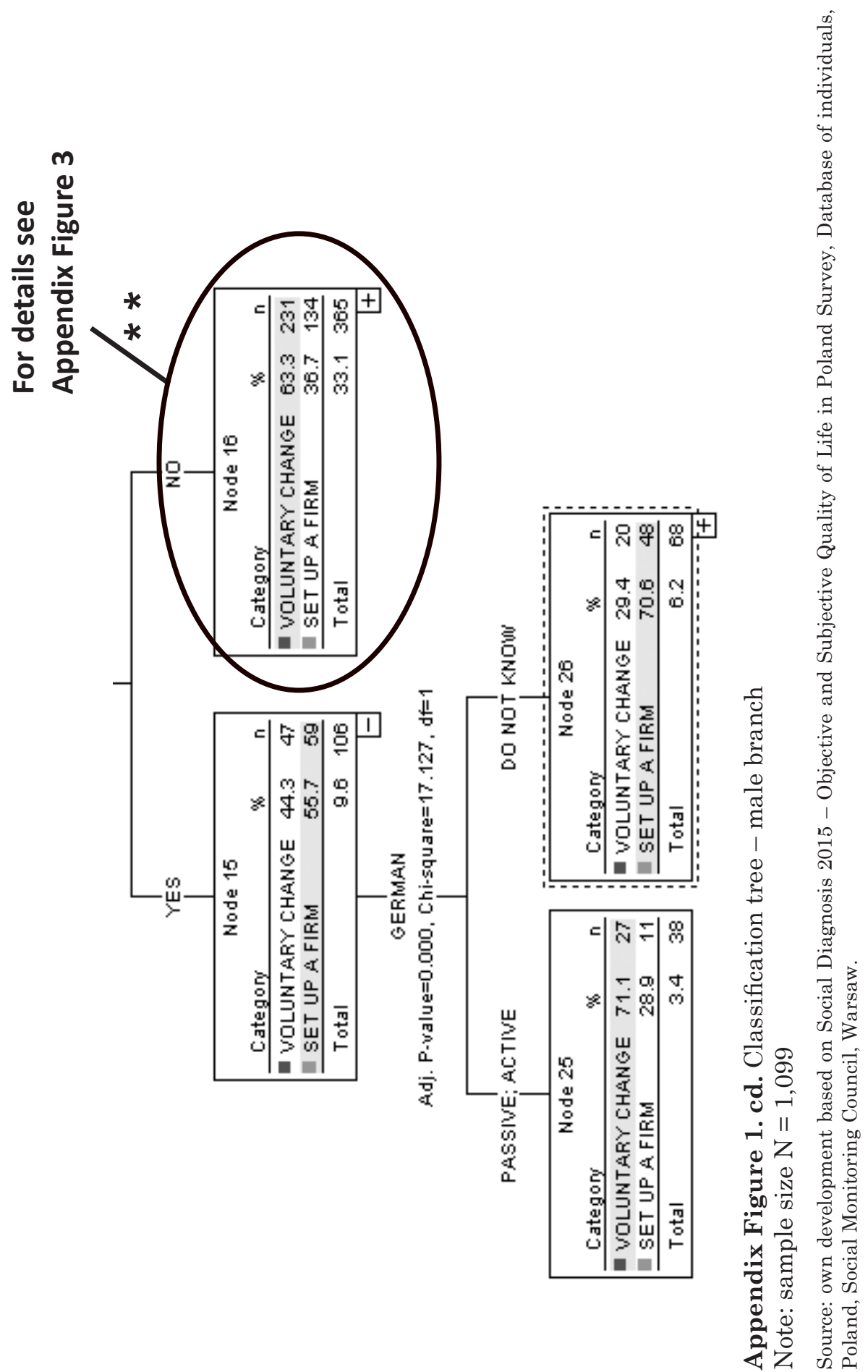


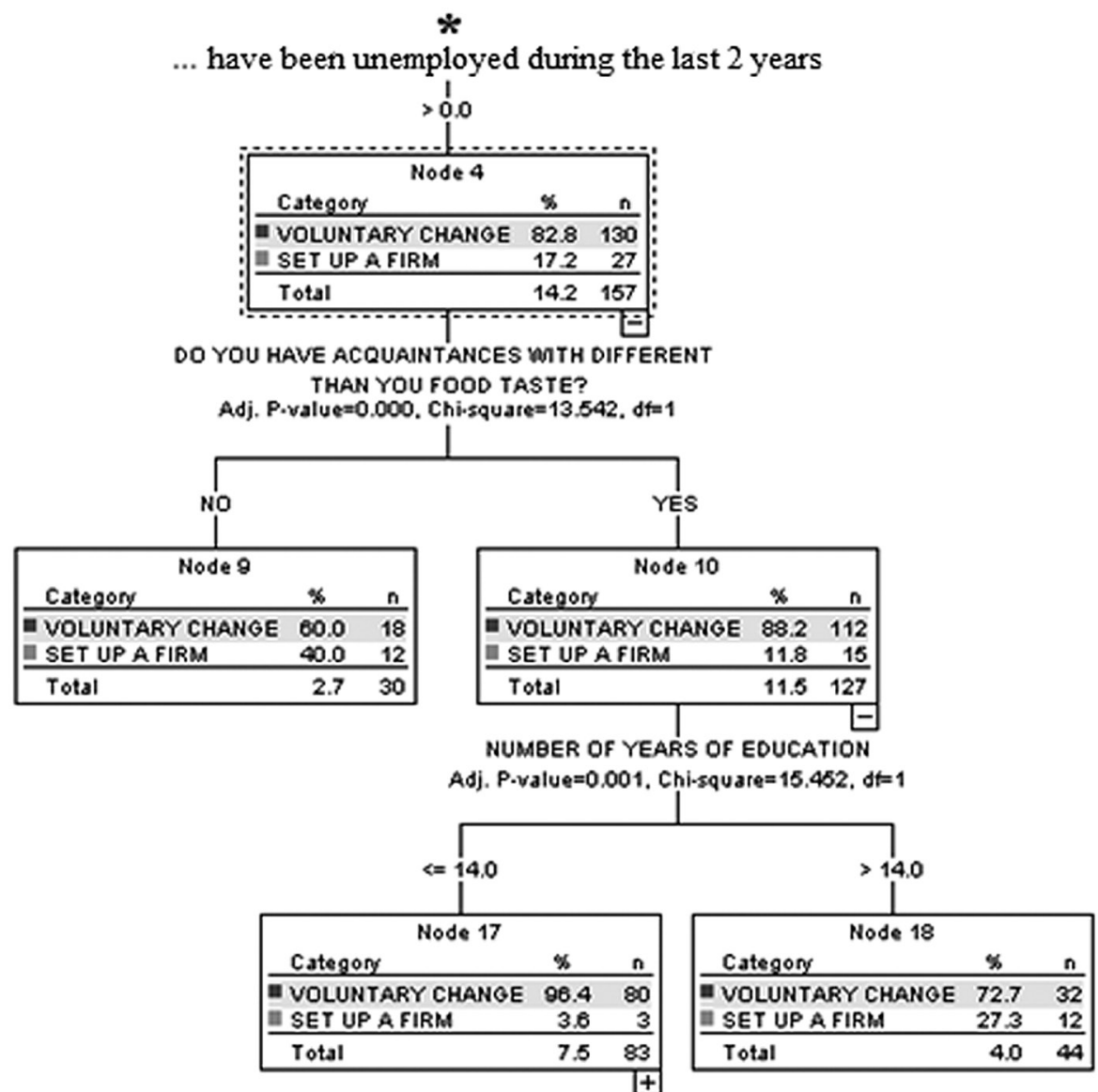

Appendix Figure 2. Classification tree - male branch "How long have you been unemployed in total during the last 2 years $->0.0$ " details

Note: sample size $\mathrm{N}=1,099$

Source: own development based on Social Diagnosis 2015 - Objective and Subjective Quality of Life in Poland Survey, Database of individuals, Poland, Social Monitoring Council, Warsaw. 


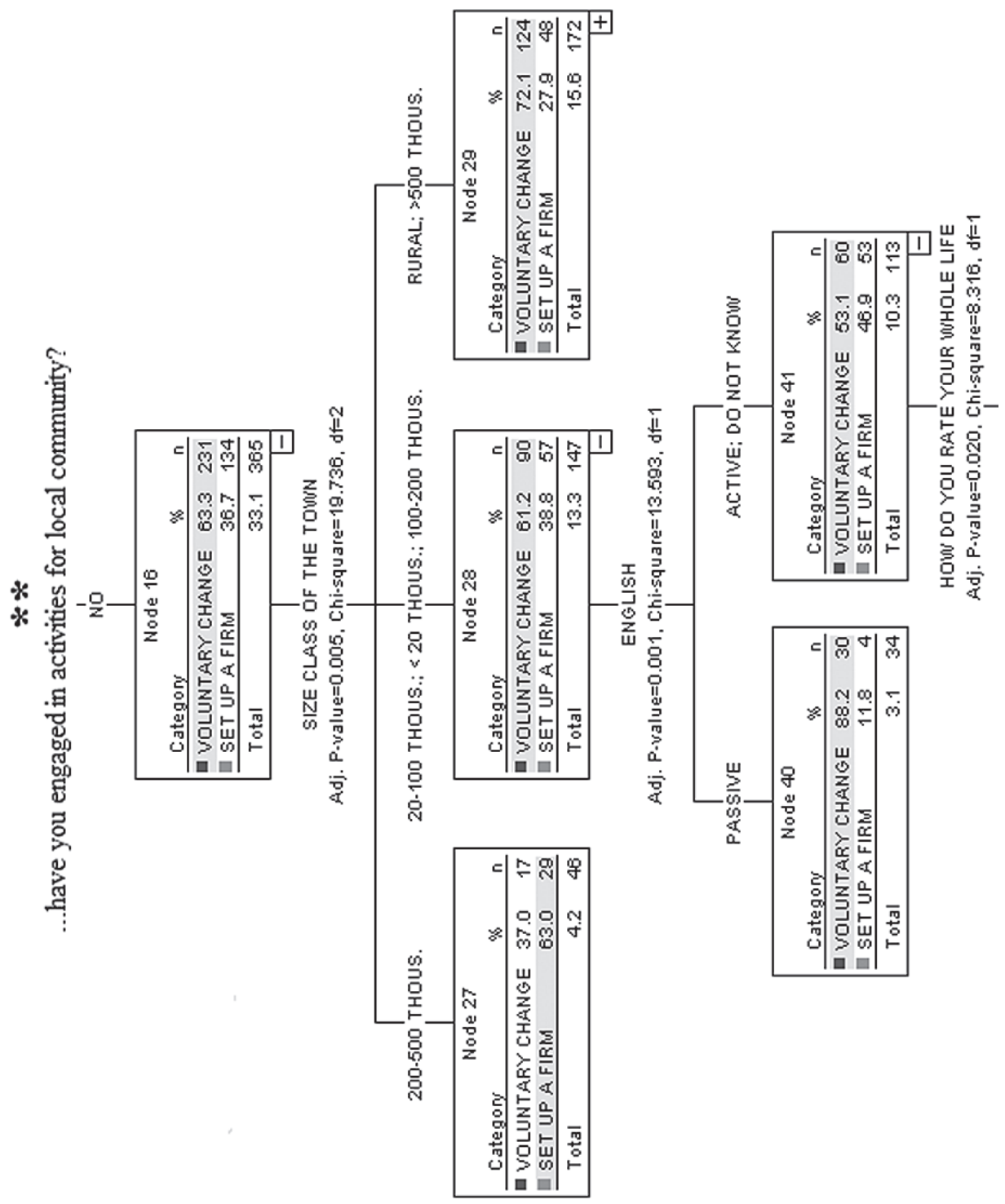



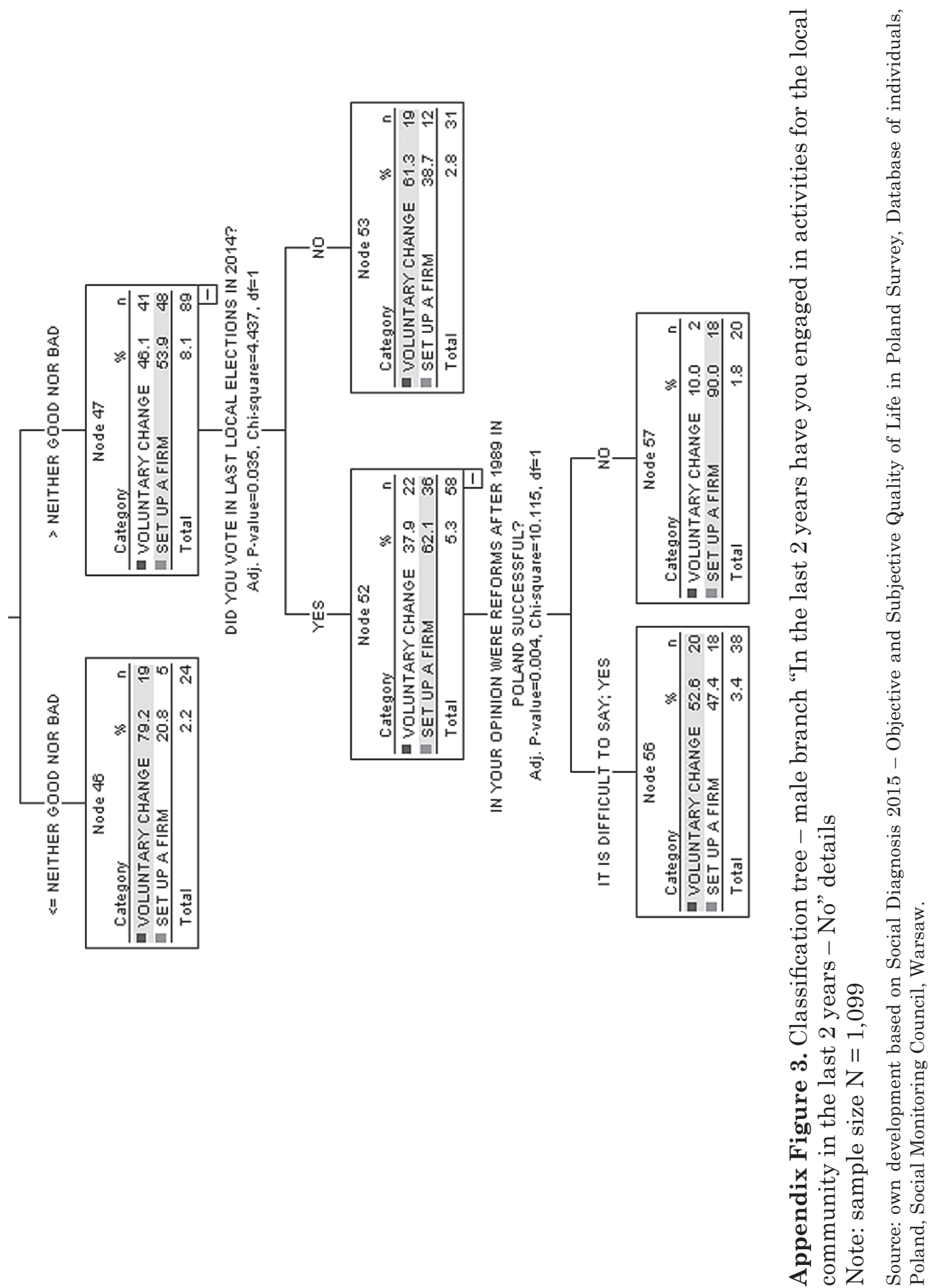


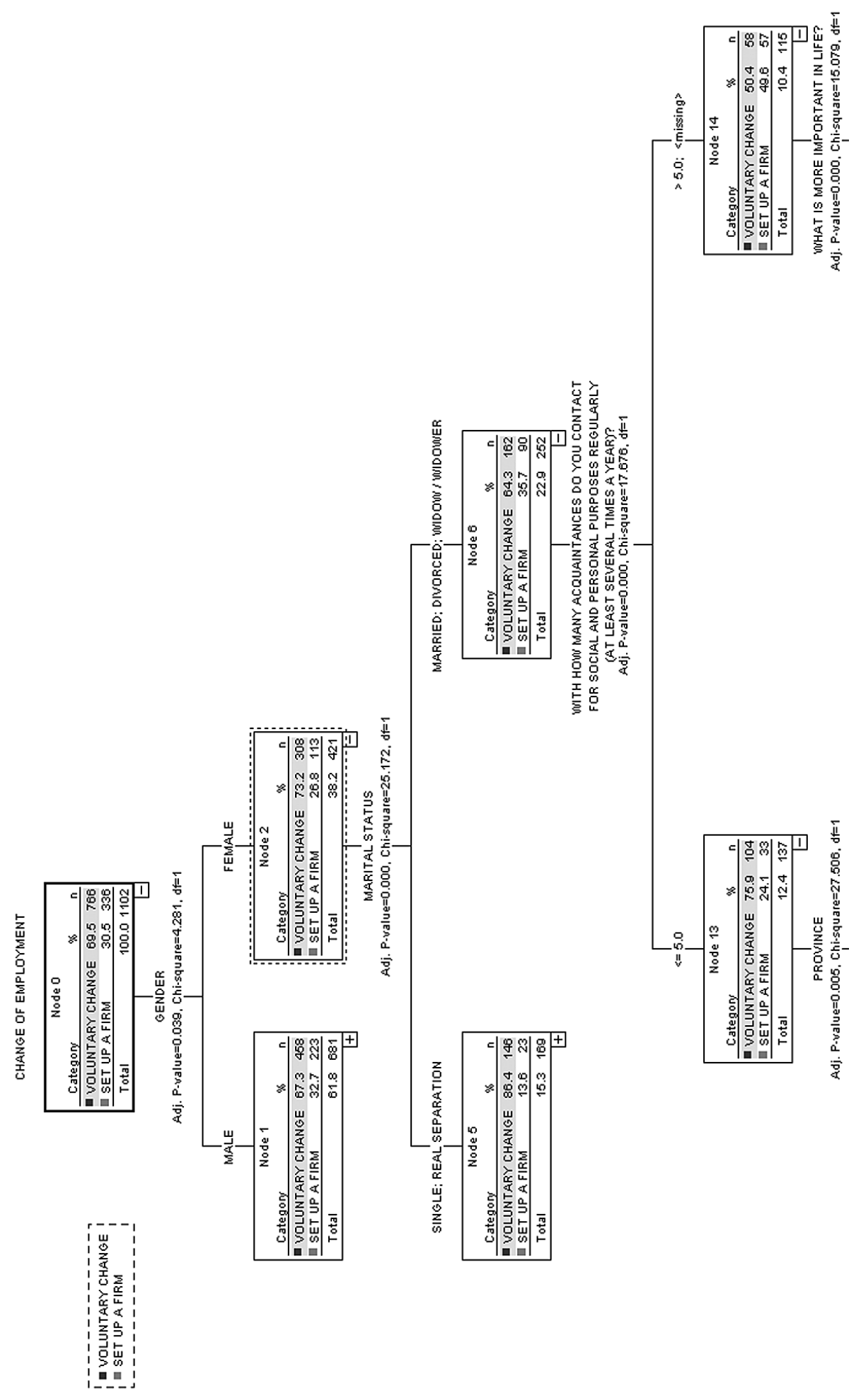




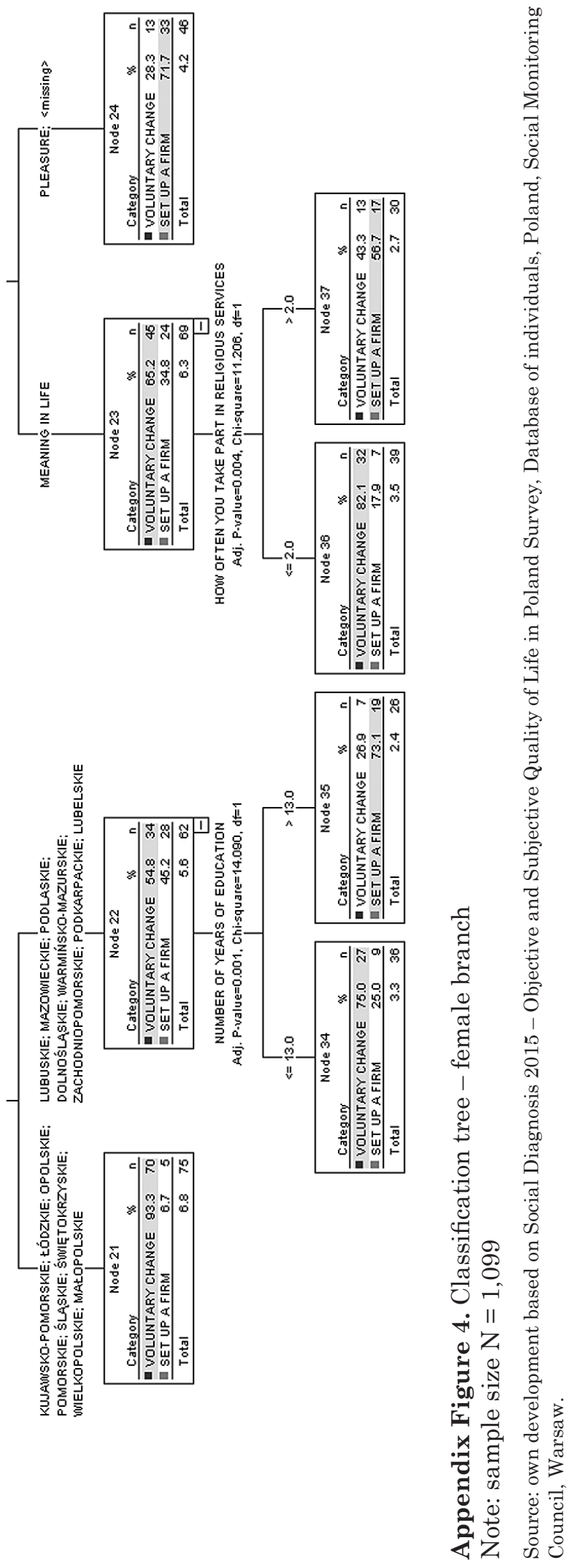




\title{
PRZEDSIĘBIORCZOŚĆ KOBIET I MĘŻCZYZN W POLSCE - ZMIANY PRACY A DECYZJA O ZAKOŻENIU FIRMY
}

\begin{abstract}
Abstrakt
Tło badań. Wcześniejsze badania pokazały, że kobiety rzadziej decydują się na założenie firmy. Jedna z kwestii, na która warto zwrócić uwagę, jest pytanie o to, czy charakterystyki kobiet i mężczyzn, którzy podjęli decyzję o założeniu firmy, różnią się od charakterystyk osób, które zmieniły miejsce pracy.
\end{abstract}

Cel badań. W artykule bada się różnice i podobieństwa między charakterystykami kobiet i mężczyzn, którzy zdecydowali się założyć firmę, a tymi, którzy zmienili miejsce pracy.

Metodologia. W badaniu wykorzystuje się dane z badania „Diagnoza Społeczna 2015 - warunki i jakość życia Polaków”. Do zweryfikowania zależności została wykorzystana metoda drzew decyzyjnych. Wśród badanych czynników można wymienić: poziom wykształcenia, wiek, region, wielkość miejscowości, zmienne społeczne i psychologiczne.

Kluczowe wnioski. Badanie pokazało, że stan cywilny i kapitał społeczny sa charakterystykami istotnymi dla kobiet, które założyły firmę, podczas gdy dla mężczyzn, którzy podjęli decyzję o założeniu firmy, istotne okazały się długość okresu bezrobocia i doświadczenie zawodowe za granica.

Słowa kluczowe: płeć kulturowa, przedsiębiorczość, przedsiębiorca, pracujący na własny rachunek. 